\title{
YHDYSVALTAIN SOISTA
}

\author{
ERKKI KIVINEN
}

Yliopiston maanviljelyskemian laitos, Helsinki

Saapunut 12. 3. 1953

Seuraava esitys perustuu osittain niihin havaintoihin, joita kirjoittaja teki syksyllä 1951 Yhdysvaltain eri puolille suuntautuneen matkansa ohella, osittain ja luonnollisesti suurelta osalta kirjallisuuteen.

Pohjois-Amerikan Yhdysvaltain soiden laajuudesta ei ole tarkkaa tietoa. Elliot ilmoittaa niitä olevan 32 milj. ha, mutta myöhemmin BAKER mainitsee vähän suuremman määrän, 37 milj. ha. Kysymyksessä ovat tällöin kaikki suot ja vedenvaivaamat sekä tulvanalaiset maat. Varsinaisten soiden osuudeksi jäänee niistä vain $7-8$ milj. ha (11).

Suurin osa Yhdysvaltain soista sijaitsee Iowan keskiosien kautta New Jerseyn keskimaille vedetyn viivan pohjoispuolella ja Minnesotan sekä Dakotan rajalinjan itäpuolella (kuva 1).

Mitä soiden jakaantumiseen eri osavaltioiden kesken tulee, niin Minnesotassa niitä näyttää olevan eniten eli 2.8 milj. ha (1). Se merkitsee $12 \%$ pinta-alasta. Niitä on erityisesti valtion pohjoisosissa. Soiden syvyys vaihtelee erittäin paljon. Yli 1/2 m syvyisiä soita ilmoitetaan olevan $2.1 \mathrm{milj}$. ha. Paikoin suot peittävät yli $37 \%$ pinta-alasta. Toisaalta etenkin Minnesotan kaakkoisosissa on soita tuskin ollenkaan. Piirroksessa 2 on esitetty soiden levinneisyys eräissä piirikunnissa. Tällöin voidaan todeta, että paikoin sikäläiset suot ovat yhtenäisiä ja laajoja, paikoin taas sangen repaleisia.

Michiganissa on n. 1.6 milj. ha eli keskim. myös $12 \%$ pinta-alasta. Tämän valtion suot tunnetaan hyvin (8). Muutamissa piirikunnissa saattaa olla jopa $34 \%$ maa-alasta turpeen peittämää. Eräissä taas soita ei käytännöllisesti katsoen ole lainkaan. Paikoin suot ovat laajoja yhtenäisiä esiintymiä, paikoin hyvin hajanaisia pieniä laikkuja siellä täällä. Eräissä seuduissa suot ovat mutkittelevia, verraten kapeita, mutta pitkänomaisia ja niihin liittyy monihaaraisia lahdekkeita. Soista on vain vähäinen osa raivattu. Sikäläisissä olosuhteissa arvokkaimpien viljelyskasvien sipulin, sellerin ja mintun tuotannossa on $2 \%$ suoalasta. Liikatuotannon pelossa ei näiden erikoiskasvien viljelyä nykyään laajenneta.

Wisconsinissa lasketaan olevan 1.2 milj. ha soita. Valtion eteläosissa sijaitsevat suot ovat verraten kalkkipitoisia. Pohjoisosien suot vaativat tehokasta kalki- 
tusta. Illinoisissa ja Indianassa ilmoitetaan olevan kummassakin useita satoja tuhansia hehtaareja soita. Iowasta en ole saanut varsinaisia lukuja tietooni, mutta siellä on lannoituskokeita järjestetty sekä ohut- että paksuturpeisilla soilla, joten soita lienee sielläkin. Ohiossa mainitaan soita olevan $60-70000$ ha. Edelleen New Yorkin valtiossa sekä Uuden Englannin valtioissa on soita. Edellämainituissa Yhdysvaltojen pohjois- ja koillisvaltioissa arvellaan olevan 6.8 milj. ha suota. Niistä on vain $5 \%$ otettu käyttöön (4).

Laajoja suoesiintymiä on edelleen Virginian ja Karolinan rajaseuduilla ja Georgiassa. Hyvin huomattava, yhtenäinen suoesiintymä, Everglades, on eteläFloridassa. Sen laajuus on n. 770000 ha. Lisäksi pieniä suoesiintymiä on muuallakin Floridassa. Missisippi-joen varsilla, Kaliforniassa, Oregonissa ja Washingto-

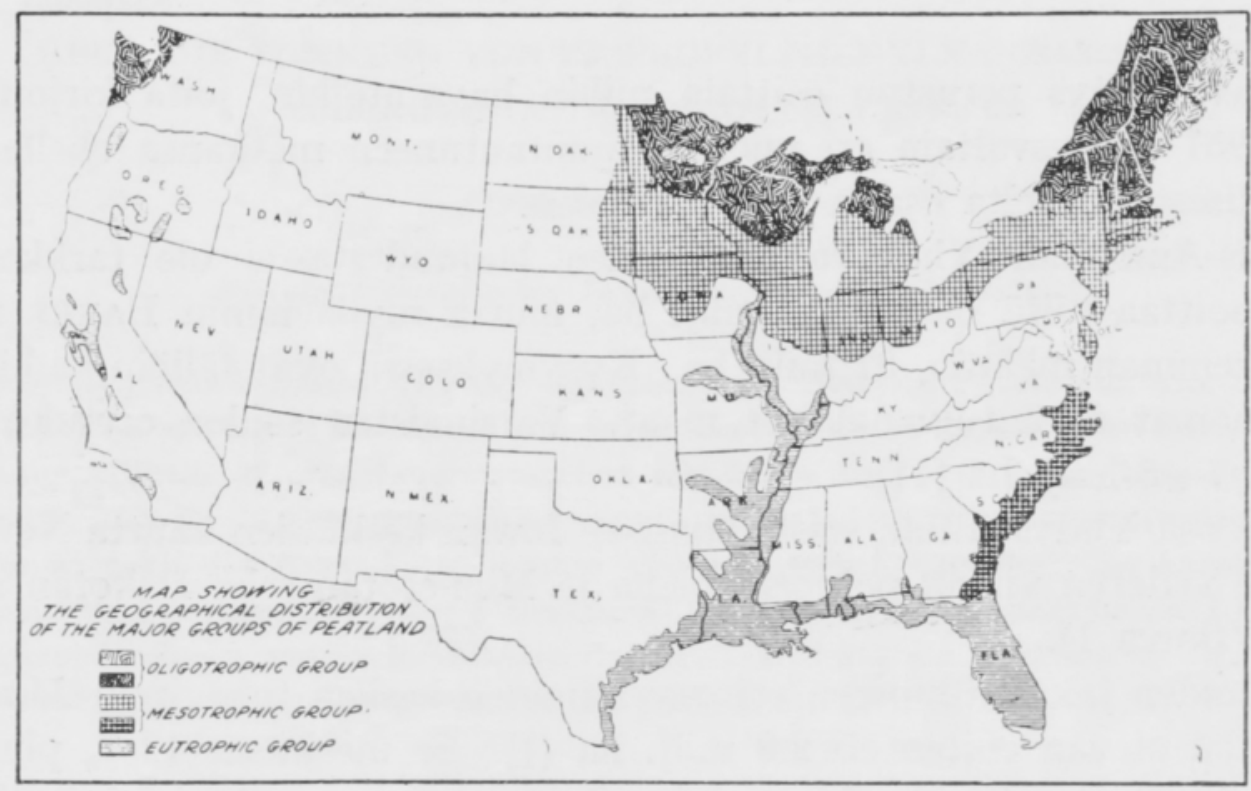

Kuva 1. Yhdysvaltain soiden levinneisyys DAchNowskY-STOKEsin mukaan.

nin valtiossa tavataan myös soita. Jokien suistomaissa niihin on sekaantunut niin paljon kivennäismaata, että viljelykseen otetuista maista on usein selvä suon luonne jo hävinnyt. Mainittava on vielä mangrovesuot, joita tavataan paikoin valtameren rannikolla esim. lounais-Floridassa. Niiden laajuus on n. 40.000 ha (3).

\section{Suoterminologiasta}

Suoterminologia ei Yhdysvalloissa ole kiteytynyt. Niinpä ei siellä enempää kuin Britanniassakaan ole vakiintunutta yleisnimeä suosta. Beltsvillen maataloudellisen tutkimuskeskuksen maantutkimustoimisto on äskettäin asettanut 12-miehisen komitean tri ABLEITERin johdolla laatimaan eloperäisten maiden luokittelua. Toimikunta on pohtinut myös soiden terminologiaa. Aikaisemmin verraten yleisesti 
käytetystä bog-sanasta soiden yleisnimityksenä näytään nyt luovuttavan. Suurimman kannatuksen on saavuttanut termi organic soil ja toiselle sijalle on tullut peat soil. Äskettäin on tälle toimikunnalle Skandinaviasta käsin ehdotettu mire-sanan käyttöön ottamista soita vastaavana yleisterminä. Se ei kuitenkaan näy saavan kannatusta. Tässä yhteydessä mainittakoon, että Alaskassa ja Kanadassa suo tunnetaan nimellä muskeg. Tämä edustanee lähinnä meikäläistä aapasuota, joskin siihen kuuluu myös selviä rahkasuomuodostumia. Englannissa soista puhuttaessa käytetään yleisimmin termejä moor tai fen ja Skotlannissa moss tai moor. Ruotsalaiset ja norjalaiset käyttävät meidän suosanamme vastineena termiä myr.

Turpeesta puhuttaessa käytetään Yhdysvalloissa peat-sanan ohella verraten
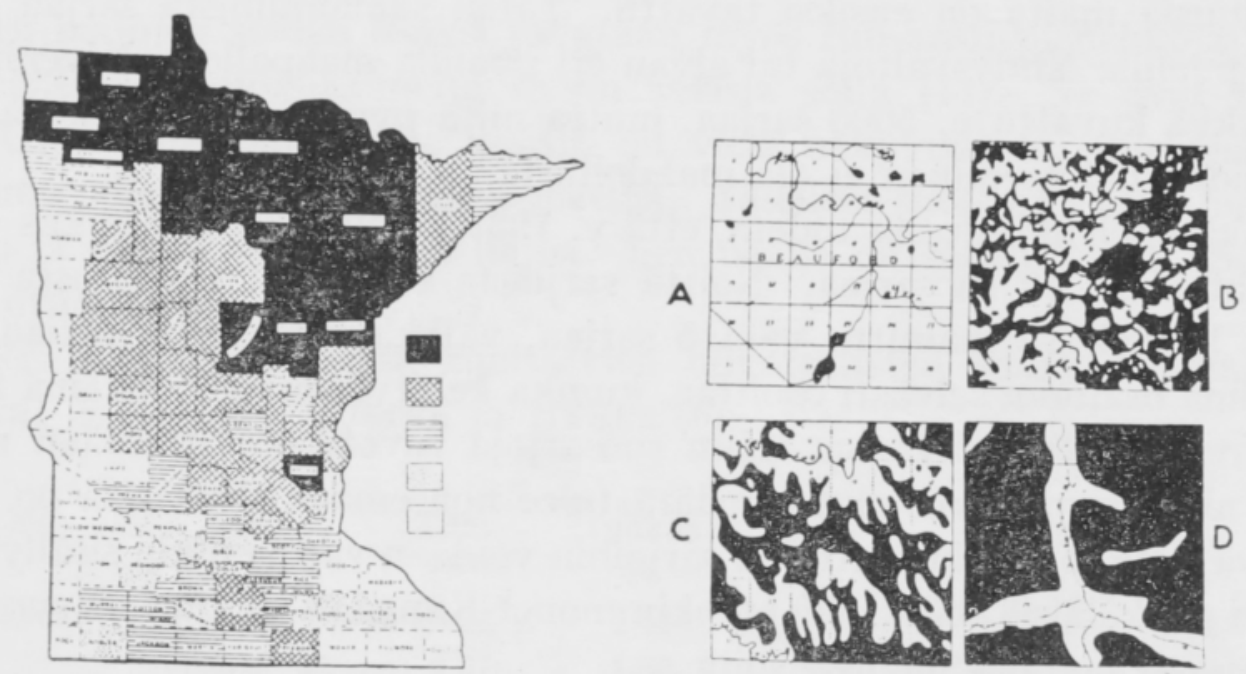

Kuva 2. Soiden suhteellinen runsaus Minnesotassa.

Vasemmassa kuvassa täysmusta $=$ runsaasti, ruudutettu $=$ kohtalaisesti , viivoitettu $=$ vähän, pilkutettu = hyvin vähän suota, valkoinen = suot puuttuvat.

Oikeassa kuvassa soiden jakaantuminen saman valtion neljässä piirikunnassa. Mustalla merkitty suota. ALWAYn mukaan.

yleisesti termiä muck tai muck soil. Osittain peat- ja muck-sanoja käytetään aivan samassa merkityksessä, mutta useimmiten muck edustaa pitkälle maatunutta turvetta, jossa ei kasvien jätteitä ole enää havaittavissa ja peat soil vähemmän maatunutta turvetta (8). Eräissä tapauksissa nimitys seuraa turpeen tuhkapitoisuutta. Tällöin muck-turpeessa on vähintäin $35 \%$ tuhkaa, ja sitä vähemmän tuhkaa sisältävät turpeet lasketaan ryhmään peat soil. Muck-termi näyttää esim. Michiganissa olevan yleisesti käytännössä ja vastaa jokseenkin tarkoin peat-sanaa. Siellä voidaan yhtä hyvin puhua hyvin maatuneesta kuin raa'asta muck-maasta. Varmaankin aika hyvin näiden eroa kuvastaa Michiganin tunnetuimman suoexpertin tri Harmerin tätä asiaa koskevaan tiedusteluuni antama vastaus: "Minulla on muck-maata, mutta naapurillani peat-maata». Suoviljelijöitäkin nimitetään muck-farmareiksi. 


\section{Soiden luokittelusta}

Soiden luokittelu on Yhdysvalloissa vielä kehitysvaiheessaan. Eloperäisten maiden luokittelua pohtivasta komiteasta on jo edellä mainittu. Se ei ole toistaiseksi tehnyt esityksiä, joskin se on jo käsitellyt eräitä kysymyksiä. Soiden luokittelussa se pyrkii noudattamaan samaa periaatetta kuin kivennäismaissakin. Mainittakoon tässä, että Yhdysvalloissa maaperän luokittelussa erotetaan ns. suuret maaryhmät, jotka jakaantuvat sarjoihin. Edellisiä ovat esim. preriamaat, chernoseemimaat, podsolimaat, harmaat podsolimaiset maat, ruskeat podsolimaiset maat jne. Eloperäiset maat muodostavat kaksi suurta maaryhmää: suot (bogs) tai soistuneet maat (half bogs). Viimeksi mainituissa turvekerros on $5-25 \mathrm{~cm}$. Ryhmään kuuluvia sarjoja nimitetään sen paikkakunnan nimen mukaan, jossa tämän kaltaisia maita on ensiksi tavattu. Täten samannimistä sarjaa saatetaan tavata eri puolilla Yhdysvaltoja tai aivan eri puolilla maapalloa. Kivennäismaista on tätä nykyä kuvattu n. 5000 sarjaa, mutta niitä pyritään yhdistelemään, koska muuten niiden hallitseminen ei ole mahdolllista.

On ehkä mielenkiintoista todeta, että v. 1933 DAchnowsky-STokes (2) kuvasi yksityiskohtaisesti 49 suosarjaa. Näistä sarjoista on edellä mainitussa komitean laatimassa luettelossa mainittu vain 5 sarjaa, vaikka siinä on kaikkiaan 39 suosarjaa. Tämä osaltaan selvästi osoittaa, kuinka kehityksen alaista tämä tutkimuksen haara vielä tätä nykyä on. Kun suosarjoja ruvetaan esittämään maapallon eri soista, niin varmaankin niiden määrä tulee nousemaan. Toisaalta on kuitenkin huomattava, että jo nyt kuvattuihin sarjoihin voidaan varmaankin sisällyttää esim. ainakin osa meikäläisiä soita, sillä etenkin monet Kanadan ja Alaskan suot muistuttavat läheisesti pohjois-Suomen soita.

\section{Trofian mukainen soiden luokittelu}

DAchnowsky-STokes (2) jakaa Yhdysvaltain suot kolmeen pääryhmään: oligotrofiset, mesotrofiset ja eutrofiset. Niiden levinneisyys esitetään kartassa 1.

Oligotrofiseen ryhmään kuuluvat suot sisältävät niukasti ravinteita ja ovat happamia. Niitä on erityisesti Yhdysvaltojen pohjoisosissa, jossa viileän ja humidisen ilmaston johdosta huuhtoutuminen on yleistä. Niitä tavataan myös Kanadassa. Yhdysvaltojen puolella niitä on Mainessa, Michiganissa, Wisconsinissa, Minnesotassa sekä Washingtonin valtiossa. Vähäisempiä esiintymiä on etelämpänä Ohiossa, Indianassa ja Illinoisissa. Samoin vuoristoissa on pienehköjä paikallisia oligotrofisia soita.

Näin laajojen alueiden suot luonnollisesti vaihtelevat luonteeltaan erittäin runsaasti. Lähellä rannikkoa ja erityisesti Mainen valtiossa ne ovat kehittyneet jo varsinaisiksi kohosoiksi. Osvald (11) kiinnittää huomiota siihen, että niistä puuttuu mutasuoreunus tai se on hyvin heikosti kehittynyt. On myös mainittava, että meikäläistä kanervaa ei tavata. Eriophorum-lajit ovat myös hiukan toisia kuin meillä. Sisämaassa suot sitävastoin eivät ole vielä ehtineet näin pitkälle, vaan siellä on runsaasti tasaisia, metsäisiä soita. Yleensä oligotrofisissa soissa on 
pinnalla keltaista tai ruskeata, hyvin hapanta $(\mathrm{pH} 3.5)$ rahkaturvetta. Sen paksuus vaihtelee muutamasta desimetristä $1-2$ metriin. Voipa sitä kohosoiden pinnalla olla jopa yli $3 \mathrm{~m}$. Alemmat turvekerrokset ovat saran-, puun- ja järviruo'on jätteiden muodostamia. Tämän kerroksen alla on tavallisesti kivennäismaa, joka osoittaa soiden syntyneen mineraalimaan soistumisen johdosta.

Eräät tähän ryhmään kuuluvat Minnesotan suot muistuttavat suuresti meidän aapasoitamme. Niiden keskiosat ovat aukeita ja vetisiä. Siellä kasvaa rahkasammalia, eräitä lehtisammalia, saroja sekä ruohoja (Eriophorum, Comarum, Equisetum, Menyanthes). Soiden reunaosat ovat metsäisiä. Turve on rahka- tai rahkasaraturvetta, joka syvempänä muuttuu saravaltaiseksi. Monin paikoin on soiden pohjalla liejua. Usein ohuehko rahkakerros peittää hyvälaatuisen turpeen samalla tavalla kuin meillä.

Näiden laajojen soiden lisäksi tavataan myös runsaasti pienehköjä kivennäismaan syvänteisiin muodostuneita hyvin vetisiä soita (11). Ne ovat tavallisesti aukeita. Usein umpeenkasvava vesistö on vielä näkyvissä tai juuri häviämässä. Soiden reunamilla on jonkin verran metsää. Tällaiset suot ovat aina hyvin syviä, jopa $10 \mathrm{~m}$ ja niiden pohjalla on liejua. Sen päällä on saraturvetta. Suon pintakerrokset ovat rahkaa.

Eräiden Mainen valtiossa sijaitsevien oligotrofisten soiden kemiallisia analyysejä ovat esittäneet Feustel ja Byers (6):

$\begin{array}{crccccrrr}\text { Cherryfield, Me } & \begin{array}{c}\text { Syvyys } \\ \mathrm{cm}\end{array} & \begin{array}{c}\text { Tilav. } \\ \text { paino }\end{array} & \begin{array}{c}\text { Tuhkaa } \\ \%\end{array} & \mathrm{pH} & \begin{array}{c}\mathrm{CaO} \\ \%\end{array} & \begin{array}{c}\mathrm{P}_{2} \mathrm{O}_{5} \\ \%\end{array} & \begin{array}{c}\mathrm{K}_{2} \mathrm{O} \\ \%\end{array} \\ \text { Sphagnum-turve } & 5-10 & 0.68 & 2.31 & 3.7 & 0.51 & 0.06 & 0.08 \\ \text { " } & 12.5-20 & 0.91 & 1.80 & 3.8 & 0.23 & 0.09 & 0.06 \\ \text { " } & 20-30 & 1.10 & 1.55 & 3.6 & 0.19 & 0.08 & 0.03 \\ \text { " } & 30-45 & 0.98 & 1.88 & 3.6 & 0.23 & 0.02 & 0.02\end{array}$

Orono, Me

\begin{tabular}{|c|c|c|c|c|c|c|c|}
\hline Sphagnum-turve & $5-10$ & - & 4.47 & - & 0.47 & 0.11 & 0.03 \\
\hline " & $12.5-20$ & - & 4.26 & - & 0.41 & 0.12 & 0.05 \\
\hline$"$ & $20-30$ & - & 2.29 & 一 & 0.56 & 0.10 & 0.03 \\
\hline " & $30-45$ & 一 & 1.51 & - & 0.41 & 0.08 & 0.01 \\
\hline \multicolumn{8}{|l|}{ Orono, $\mathrm{Me}$} \\
\hline Sphagnum-turve & $7.5-15$ & 0.49 & - & 3.8 & - & 一 & - \\
\hline " & $15-22.5$ & 0.41 & - & 3.9 & - & - & \\
\hline " & $22.5-30$ & 0.42 & - & 3.8 & - & - & \\
\hline$"$ & $60-90$ & 0.65 & - & 4.0 & - & - & \\
\hline 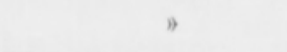 & $90-120$ & 0.59 & - & - & - & -- & \\
\hline Metsäturve & $130-133$ & 0.77 & - & - & - & - & \\
\hline
\end{tabular}

Oligotrofisten turpeiden alhainen tilavuuspaino, hapan reaktio, vähäinen tuhkapitoisuus ja erityisesti niukka kalkkipitoisuus käyvät asetelmasta selvästi ilmi.

Mesotrofisia soita tavataan Yhdysvalloissa itärannikolla lähinnä Virginian, Karoliinan ja Georgian valtioissa sekä länsirannikolla Washingtonin valtiossa. Sisämaassa niitä on laajana vyöhykkeenä New Jerseyn länsipuolella ja aikaisemmin 


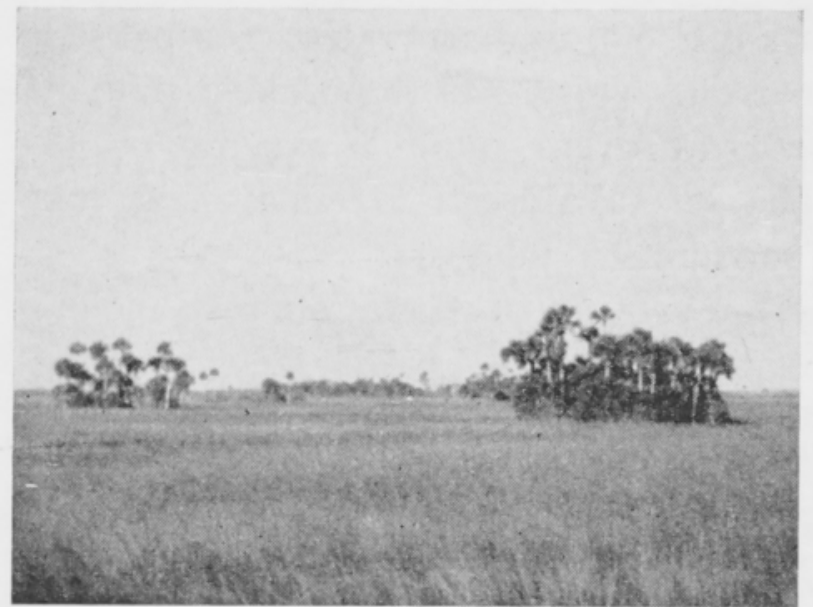

Kuva 3. Floridan Everglades-nimisellä laajalla suoalueella on Cladium leimaa-antava laji. Saarekkeilla kasvaa kookospähkinäpuita. Valok. E. K.

mainittujen oligotrofisten soiden eteläpuolella alueella, jonka eteläraja noudattelee maajään ulointa rajaa. Täten niitä on etenkin Ohiossa, Indianassa, Illinoisissa, Michiganissa, Wisconsinissa, Minnesotassa ja Iovassa. Ne soveltuvat hyvin monipuoliseen kasvintuotantoon ja niiden taloudellinen arvo on tämän takia erittäin huomattava.

Sisämaassa tämän ryhmän luonnontilaiset suot ovat tavallisesti metsää kasvavia. Turvekerroksissa on runsaasti puunjätteitä, saran- ja järviruo'on jätteiden ohella. Turve on tavallisesti hyvin maatunutta, väriltään tummanruskeata tai melkein mustaa (muck). Siinä on huomattavasti runsaammin kasvinravinteita kuin oligotrofisissa soissa. Samoin suot ovat lievemmin happamia, jopa välistä lievästi alkaalisiakin. Turvekerrokset ovat tavallisesti verraten ohuita. Viljelytoimenpiteiden johdosta monet aikaisemmin turpeen peittämät alueet ovat nyttemmin menettäneet suon luonteensa. Paikoin aridisissa olosuhteissa näiden soiden pinnalle kerääntyy runsaasti suoloja, mistä saattaa aiheutua vaikeuksia niiden viljelyssä.

Rannikkoseutujen mesotrofiset suot ovat alkuaan olleet myös metsäisiä, mutta ne ovat kehittyneet jonkin verran pitemmälle kuin sisämaan suot. Tämä näkyy niiden kuperista pinnanmuodoista. Useimmiten ne ovat myös happamampia kuin sisämaan suot. Matalan sijaintinsa vuoksi ne voivat ajoittain joutua veden peittoon. Turpeessa on runsaasti erilaisia puunjätteitä. Etenkin sypressin (Taxodium distichum) muodostama turve on yleistä. Tähän ryhmään kuuluu n. 550000 ha laajuinen Dismal Swamp Virginian ja Pohjois-Karolinan rajaseuduilla sekä Okefinokee Swamp Georgiassa. Ensiksi mainitusta on nyttemmin 180000 ha otettu viljelykseen ja muu osa muodostettu luonnonpuistoksi.

Pohjois-Karolinasta ovat Feustel ja Byers (6) analysoineet erään profiilin:

$\begin{array}{lccccc} & \text { Syvyys } & \text { Tuhkaa } & \mathrm{CaO} & \mathrm{P}_{2} \mathrm{O}_{5} & \mathrm{~K}_{2} \mathrm{O} \\ & \mathrm{cm} & \% & \% & \% & \% \\ \text { Kanervaturve } & 0-7.5 & 7.17 & 0.58 & 0.13 & 0.04 \\ \text { " } & 7.5-22.5 & 2.33 & 0.24 & 0.07 & 0.03 \\ \text { " ja lietettä } & 30-45 & 2.08 & 0.11 & 0.03 & 0.01 \\ \text { Lieteturve } & 60-75 & 6.74 & 0.42 & 0.03 & 0.02 \\ \text { Metsäturve } & 90-105 & 27.05 & 0.35 & 0.13 & 0.11\end{array}$

Todennäköisesti samasta suosta, mutta hiukan eri syvyyksiltä otettujen näytteiden tilavuuspainot ja reaktiot ovat vaihdelleet: 


$\begin{array}{cccc} & \text { Syvyys cm } & \text { Tilav.paino } & \mathrm{pH} \\ \text { Kanerva-turve } & 0-7.5 & 0.53 & 4.0 \\ \text { " } & 7.5-15 & 0.85 & \\ \text { " } & 15-22.5 & 0.88 & 3.5 \\ \text { " } & 22.5-30 & 0.80 & - \\ \text { Lietepit.-turve } & 30-37.5 & 0.94 & \\ \text { Metsäturve } & 37.5-45 & 0.98 & 3.1 \\ & 60-75 & 1.05 & 3.5 \\ & 90-105 & 1.16 & 3.7\end{array}$

Eutrofisiin soihin kuuluvat Floridan laajat Cladium-suot sekä Kalifornian, Oregonin ja Washingtonin valtioiden laaksoissa tavattavat Scirpus- ja Phragmitessuot. Lähinnä tähän ryhmään lasketaan Missisippijoen varsilla ja suistomaassa tavattavat laajat Arundinaria-suot sekä Floridan lounaisrannikolla tavattavat mangrovesuot.

Eutrofisten soiden turvekerrostumat ovat syntyneet suurien sarojen ja heinien ja ruohojen jätteistä tulvan alaisille maille Turpeet ovat tavallisesti neutraaleja tai lievästi alkaalisia. Ne sisältävät runsaasti kivennäisaineksia ja typpeä. Usein niiden pinnalle rikastuu melkoisesti suoloja, jolloin voi muodostua tyypillisiä alkalisia suolamaita. Väriltään Floridan turpeet ovat jokseenkin mustia, muualla sijaitsevat vähän vaaleampia tai harmaan ruskeita.

Laajin yhtenäinen Cladium-suoalue on nimeItään Everglades ja peittää Floridan niemimaan eteläosan keskuksen. Se alkaa Ockechobee-nimisestä järvestä pohjoisessa ja jatkuu siitä etelään Meksikon lahdelle saakka. Se on n. $160 \mathrm{~km}$ pitkä ja n. $80 \mathrm{~km}$ leveä. Viljely- ja kuivatustoimenpiteiden johdosta ohuemmat turvekerrokset ovat kuluneet, nmn että kun 1900 seudulla turvekerrosten laajuus oli 850000 ha, suota arvioidaan nykyään olevan 770000 ha (3). Tämä suo edustaa $80 \%$ koko Floridan turve-esiintymistä.

Everglades sijaitsee hyvin matalalla. Niinpä ennen kuivattamista suon pinta Ockechobee-järven luona oli vain $6 \mathrm{~m}$ meren pinnan yläpuolella. Suo on hyvin tasainen (kaltevuus pohjoisesta etelään on vain $4 \mathrm{~cm} / \mathrm{km}$.). Sen molemmin puolin on laajoja, mataloita hiekkakankaita. Suurin osa turvekerrostumista sijaitsee kalkkikiven tai kalkkipitoisen merkelin päällä. Turvekerrosten paksuus vaihtelee melkoisesti. Pohjoisessa lähellä Ockechobee-järveä saattaa olla $3-31 \frac{1}{2}$ m turvetta, mutta suon reunamilla vain muutamia kymmeniä senttimetrejä. Ennen viemäröintiä ja Ockechobee-järven patoamista koko suoalue usein joutui tulvan alle,

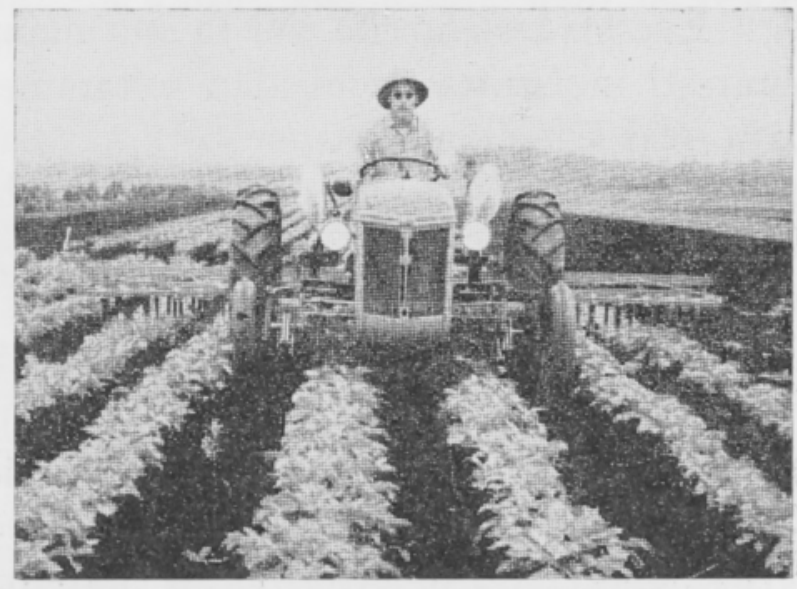

Kuva 4. Koneellistettua vihannesten viljelyä Michiganissa. 
mutta nykyään ylimääräinen vesi johdetaan mereen. Kuivatus- ja veden säännöstelytoimenpiteet aloitettiin v. 1910 seuduissa. Maan tasaisuudesta ja suon painumisesta johtuen pumppulaitokset ovat välttämättömiä. Niiden avulla on n. 60000 ha otettu sangen monipuoliseen kasvintuotantoon.

Monet pitkät ja komeat valtaojat halkovat tätä rannatonta suoaluetta. Niiden varressa kulkee säännöllisesti hyvä asfalttitie. Niitä pitkin on mahdollista nopeasti ja vaivattomasti päästä tutustumaan luonnontilaiseen, erikoislaatuiseen subtroopilliseen ja meidän oloistamme niin suuresti poikkeavaan suohon. Ja saman tien varressa avautuu myös silmänkantamattomia suoviljelyksiä moninaisine viljelykasveineen.

Mitä kasvillisuuteen tällä suurella suoalueella tulee, niin se luonnollisesti vaihtelee erittäin paljon Etenkin alueen pohjoisosissa on laajoja alueita, joissa Cladium on leimaa-antavana Tämä laji voi olla jopa yli $2 \mathrm{~m}$ korkuinen. Sen lehtien reunat ovat sahanterävät (engl. nimi sawgrass). Monin paikoin on tällaisen kasvuston läpi tunkeutuminen ilman erikoisvarusteita aivan mahdotonta. Tämän lajin joukossa ja erityisesti vetisissä painanteissa kasvaa Peltranda virginica, Sagittaria longifolia, Nymphea odorata ja Pontederia cordata. Hajanaisesti siroteltuna tavataan Rhynchospora-lajeja, Andropogon glomeratus ja Cyperus speciosus. Paikoin on myös eräitä saniaisia (2). On helposti ymmärrettävää, että tällainen rehevä kasvillisuus on tehokas turpeenmuodostaja.

Monin paikoin Everglades-alueella leveälehtiset, alati vihannoivat puut ja monet pensaat pyrkivät työntymään Cladium-kasvuston tilalle. Niinpä esim. Ockechobee-järven rannalle on verraten äskettäin muodostunut tiheitä Anona glabran muodostamia metsiköitä (engl. nimeltä Custard apple). Näihin liittyy usein runsaasti pensaikkoja ja monenlaisia ruohoja. Hiekkakankaisiin rajoittuvilla suon osilla kasvaa sypressejä (Taxodium distichum) sekä monia leveälehtisiä puita kuten vaahteroita, saarnia, lehmuksia, tammia, palmuja sekä suuri joukko pensaita, ruohoja ja heiniä.

Järvien rantamilla ja kanavissa vallitsevat monet hyvin kosteissa olosuhteissa ja suorastaan vedessä viihtyvät lajit. Erikoisen kauniin violetin leiman antavat paikoin sangen laajat vesihyasintin (Piaropus crassipes) kasvustot.

Everglades-alueelta voi tavata monia sellaisia paikkoja, jotka ensi näkemältä suuresti muistuttavat meidän soitamme, mutta lähempi tarkastelu osoittaa, että lajit ovat sittenkin verraten vieraita. Laajojen rämemäisten soiden ohella tavataan myös selvästi korpityyppejämme muistuttavia. Erikoisluonteisia ovat alueen eteläosissa laajat’ aukeat Cladium-suot, joissa oli siellä täällä kookospähkinäsaarekkeita.

Kuten edellä on käynyt esille tällaisella subtroopillisella suolla on erittäin vaikeata liikkua jo sikäläisen leikkaavan ja pistävän luonnontilaisen kasvillisuuden takia. Edelleen koko Everglades-alueella pohjavesi on sangen korkealla, niin että sekin asettaa suuria esteitä. Mainittakoon, että näitä soita tutkittaessa on menestyksellä käytetty moottorirekeä. Matelijat ja villieläimet saattavat lisäksi aiheuttaa soiden tutkijalle sellaisia vaaroja, joita me emme soita tutkiessamme osaa aavistaakaan. Kirjoittajan havainnot luonnontilaisista soista rajoittuvatkin kokonaan maan- 
tieltä tehtyihin. Ja silloinkin jo eräässä paikassa ajoimme n. 111/2 m pitkän käärmeen yli autolla.

Mitä Evergladesin turpeisiin tulee, niin vesistöjen luona tavataan jokseenkin selvää liejua, jossa ei näy mitään kasvien jätteitä. Kuivana se on kovaa ja muruista, kosteana jonkin verran muovailtavaa. Varsinaiset turpeet ovat erittäin hyvin maatuneita, mutta niissä on kuitenkin vielä siellä täällä selviä saran tai Cladiumin säikeitä. Ne ovat rakenteeltaan löyhiä, eivätkä kosteinakaan muovailtavia. Evergladesalueen turpeiden kemiallisia ominaisuuksia ovat selvittäneet DAvis (3), Hammar (7), Waksman (12) sekä Feustel ja Byers (6). Seuraavassa esitetään viimeksi mainittujen suorittamia analyysejä:

Delle Glade, Fla

Cladium-turve

"

$\begin{array}{cccc}\begin{array}{c}\text { Syvyys } \\ \text { cm }\end{array} & \text { Tilav. } & \text { Tuh- } & \mathrm{N} \\ \text { paino } & \text { kaa } \% & \%\end{array}$

$$
\mathrm{pH}
$$

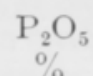

$\underset{\%}{\mathrm{CaO}}$

$\mathrm{K}_{2} \mathrm{O}$

(a)

$0-10$
$10-15$
80
122
157
$236-240$

$\begin{array}{lrr} & & 8.54 \\ 0.6 & 6.67 \\ 0.97 & 10.67 \\ 0.94 & 7.60 \\ 0.99 & 8.63 \\ 1.0 & 17.82\end{array}$

1.87
1.81
2.22
1.94
2.70
2.07

5.3

0.22

2.97

0.07

6.2

0.10

2.95

0.03

Miamin kanava, Fla

Lieju

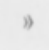

$\begin{array}{ccc}37-75 & 0.9 & 47.57 \\ 105-120 & 1.0 & 10.27 \\ 155-170 & 1.0 & 22.92\end{array}$

1.94
2.16
2.33

6.3

0.04

5.20

0.02

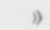

Cleviston, Fla

Cladium-turve

" hiekkainen

$\begin{array}{rrr}0-10 & - & 11.49 \\ 25-40 & - & 7.73 \\ 50-65 & - & 28.07 \\ 75-90 & - & 75.32\end{array}$

$\begin{array}{ll}1.74 & 5.5 \\ 1.76 & 5.8 \\ 1.99 & 5.9 \\ 1.89 & 6.1\end{array}$

6.3

0.03

3.74

0.01

6.7

0.01

4.21

0.02

7.1

0.01

3.88

0.01

Turpeiden melko suuresta tuhkapitoisuudesta ja täydellisestä maatuneisuudesta johtuen niiden tilavuuspaino on erittäin korkea. Typpipitoisuus on itse asiassa verraten alhainen. Kalkkia on jokseenkin aina runsaasti. Cladium-turpeet ovat selvästi pintaosissaan liejuja happamampia. Turvekerrosten painuminen on sikäläisissä olosuhteissa erittäin voimakasta. Se johtuu ensinnäkin suon suuresta

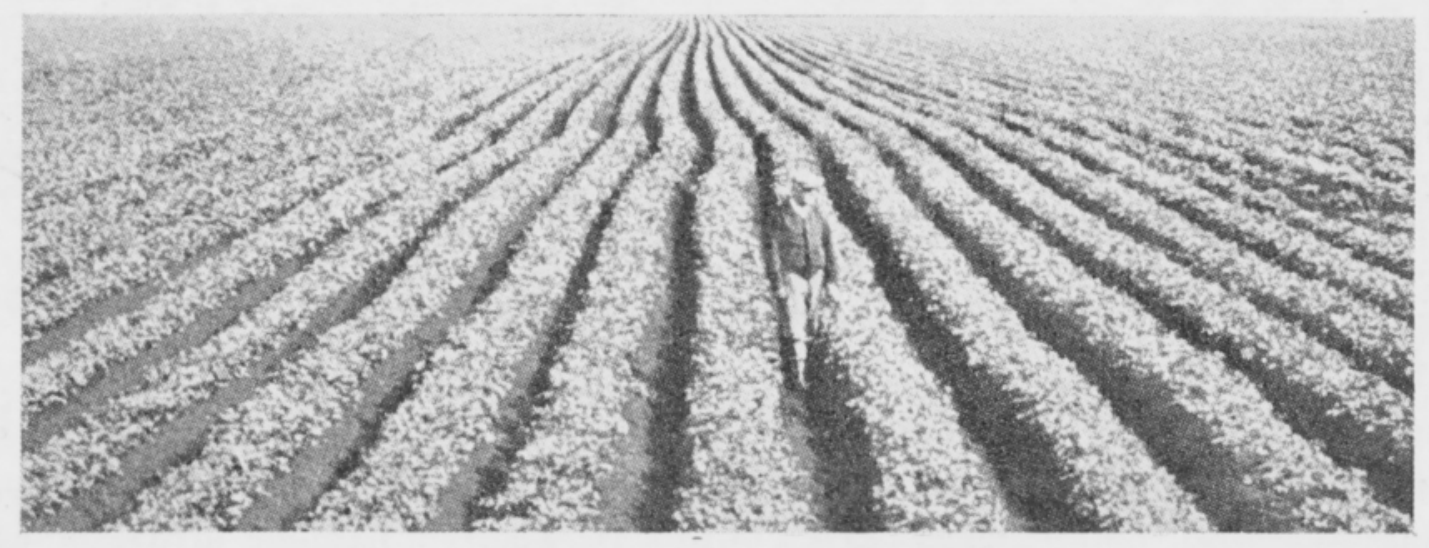

Kuva 5. Vihannesten viljely on hyvin yleistä ja laajaa kaikkialla Yhdysvaltain soilla. 
vesipitoisuudesta ennen kuivatusta sekä myöhemmin tapahtuvasta nopeasta maatumisesta. Syväturpeisilla soilla painuminen voi 20 vuoden kuluessa olla jopa $150 \mathrm{~cm}$. Se on suurimmillaan heti kuivatuksen jälkeisenä aikana, mutta supistuu myöhemmin 3-4 cm vuodessa. Varsin oleellisesti vaikuttaa painumiseen suon pohjaveden korkeus. Jos pohjavesi pidetään n. $60 \mathrm{~cm}$ syvyydellä, on suon painuminen keskimäärin $3 \mathrm{~cm}$ vuodessa $20-30$-vuotisen havaintosarjan mukaan. Eräällä koealueella, jossa pohjavesi on pidetty vain $45 \mathrm{~cm}$ syvyydessä, on suon kuluminen supistunut sitävastoin $2 \mathrm{~cm}$ :iin vuodessa (5).

Rannikkoseuduilla, joissa suolainen tai murtovesi ei ole kovin voimakkaan aaltoilun alaisena, tavataan paikoin mangrovesoita. Niitä on etenkin Floridan niemimaan lounaisrannikolla ja muuallakin Meksikon lahden rantamilla (3). Vallitsevana puuna on Rhizophora mangle, joka peittää laajoina yhtenäisinä, tiheinä kasvustoina laajat alat. Sen ilmajuuret antavat mangrovesoille omalaatuisen ulkonäön matalan veden aikana. Paikoin on mangrovesoilla sangen runsas heinä- ja ruohokasvillisuus. Turve on erittäin pitkälle maatunutta ja sisältää usein huomattavasti kivennäisaineita. Mangrovesuot ovat toistaiseksi luonnontilassa ja pysynevätkin sellaisina.

Eutrofisia soita tavataan myös Kaliforniassa n. 200.000 ha laajuisena esiintymänä (13). Ne sijaitsevat kahden suuren joen suistomaassa. Nämä suot ovat alkuaan olleet hyvin reheviä, erilaisten Scirpus-lajien muodostamia. Phragmites, monet Juncus-lajit sekä Typha latifolia ovat olleet yleisiä. Nyttemmin suot on otettu viljelyyn. Siinä tarkoituksessa on rakennettu laajoja pengerryksiä ja kanavia, jotka toisaalta estävät tulvavesien pääsyn alueelle, toisaalta tekevät tehokkaan veden saannin mahdolliseksi. Viljeltyjen soiden pinta on jopa $6 \mathrm{~m}$ meren pintaa alempana. Soiden pohjamaa sisältää paikoin runsaasti alkalisuoloja, mutta veden runsauden johdosta ne eivät kuitenkaan vaikuta epäedullisesti kasvintuotantoon. Turve on erittäin hyvin maatunutta ja siinä on runsaasti lietettä. Se on reaktioltaan tavallisesti neutraalia tai jopa lievästi alkaalista. Näitä soita käytetään erittäin tehokkaaseen vihannesviljelyyn. Samantapaisia soita on myös etelä-Oregonissa.

Edelleen Washingtonin valtion vuoristoseuduissa tavataan eutrofisia soita. Ne sijaitsevat vuoriston painanteissa ja ovat välistä sangen syviä. Ne ovat alkuaan olleet metsäisiä soita. Seetripuun (Thwja plicata) ja Abies grandisin ohella niissä on kasvanut leppiä ja pajuja. Kosteammat paikat ovat muistuttaneet suuressa määrin edellä mainittuja Kalifornian Scirpus-soita. Niissä on kasvanut lisäksi runsaasti järviruokoa, monenlaisia saroja ja ruohoja sekä kosteutta sietäviä lajeja. Eräissä tutkituissa soissa on ollut pinnalla 2-3 m keskinkertaisesti maatunutta ScirpusPhragmites-turvetta. Sen alla on ollut 10-11 $\mathrm{m}$ harmaata tai harmaan ruskeata lietepitoista hienojakoista turvetta, jossa on lisäksi puiden jätteitä.

Erään Washingtonin valtiossa sijaitsevan suon luonnetta kuvaavat seuraavat. analyysit (6):

$\begin{array}{lcccccc} & \begin{array}{c}\text { Syvyys } \\ \mathrm{cm}\end{array} & \begin{array}{c}\text { Tuhkaa } \\ \%\end{array} & \mathrm{pH} & \begin{array}{c}\mathrm{CaO} \\ \%\end{array} & \begin{array}{c}\mathrm{P}_{2} \mathrm{O}_{5} \\ \%\end{array} & \begin{array}{c}\mathrm{K}_{2} \mathrm{O} \\ \%\end{array} \\ \text { Metsäsaraturve } & 0-15 & 10.84 & 4.6 & 1.29 & 0.43 & 0.09 \\ \text { Ruohosaraturve } & 25-40 & 6.51 & 4.5 & 1.44 & 0.25 & 0.03 \\ \text { Scirpus-saraturve } & 45-60 & 11.49 & 5.2 & 1.96 & 0.21 & 0.07\end{array}$




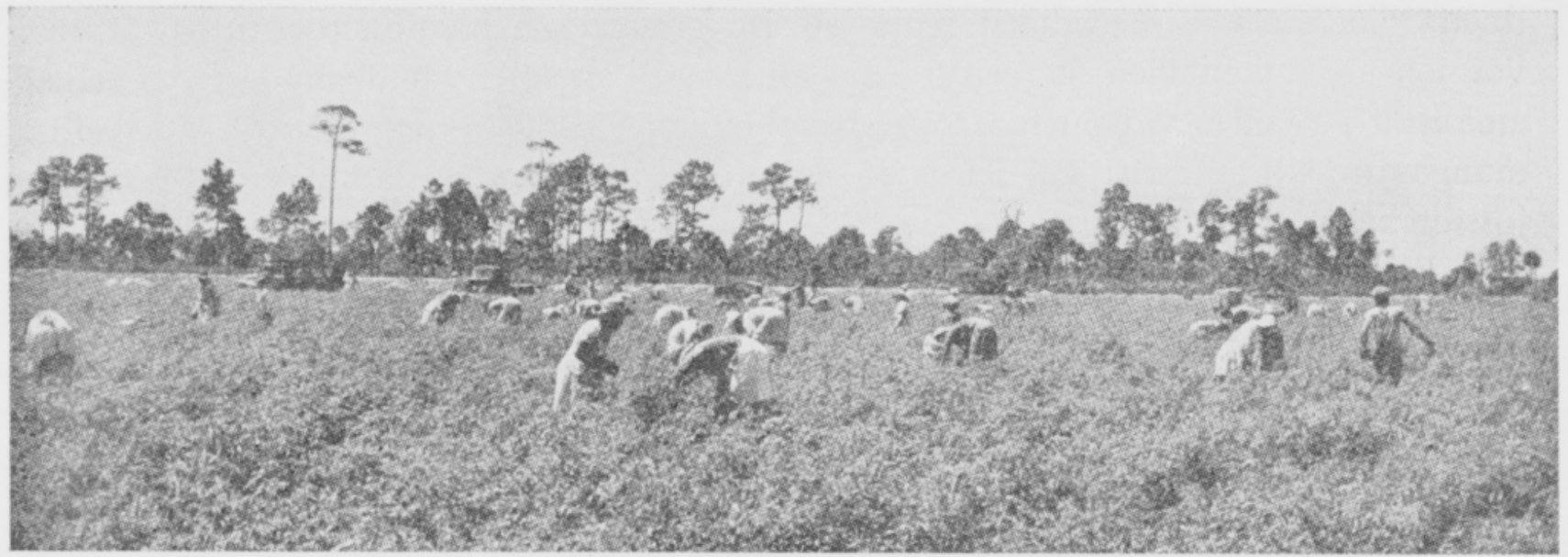

Kuva 6. Pavun korjuuta Floridan Everglades-alueella.

Muita soiden luokitteluja

Edellä esitetyn DAchnowsky-STOKEsin luokittelun lisäksi on käytännössä myös soiden syntytapaan perustuva ryhmittely (8). Sen mukaan eroitetaan veteen kerrostuneet suot, aukeat sarasuot (marsh), metsäiset suot ja rahkaiset suot.

Michiganissa HARMER (8) luokittelee suot niiden pintaturpeen kalkkipitoisumden ja reaktion mukaan kolmeen ryhmään:

1. Niukasti kalkkia sisältävät, hyvin happamat suot. Niiden $\mathrm{pH}$ on 4.5 tai sitä alempi. Luontaisen kasvillisuuden tärkeimmät edustajat ovat mustikka, karpalo, Cassandra, rahkasammalet, lehtikuusi, kuusi, eräät ruohot, koivu ja haapa.

2. Kalkkipitoiset suot, reaktioltaan $\mathrm{pH} 4.6-7.0$. Luonnontilaisilla soilla kasvaa saarnia, jalavaa, vaahteraa, seetripuuta, lehtikuusta, leppää sekä pajua ynnä yleisesti suosaroja, ruohoja, järviruokoa ja kaisloja ynnä välistä myös koivua ja haapaa.

3. Alkaliset suot, joiden reaktio on $\mathrm{pH} 7$ tai yli sen. Luontainen kasvillisuus suurin piirtein kuten edellä. Ruoho- ja sarakasvillisuus on kuitenkin usein yleisempää, koska metsä on tavallisesti palanut.

Ensimmäiseen ryhmään kuuluvia soita tavataan eräissä Yhdysvaltain koillisvaltioissa laajoina yhtenäisinä esiintyminä. Michiganissa ne peittävät pienehköjä alueita siellä täällä. Usein niitä on myös kalkkipitoisten soiden reunamilla. Näitä happamia soita ei voida viljellä kalkitsematta. Silloinkin pintaturpeen alla olevat happamet kerrokset helposti vaikuttavat epäedullisesti satoon.

Lievästi happamien soiden reaktio ei kuitenkaan aina ole samanlainen kaikissa syvyyksissä. Usein syvemmät kerrokset voivat olla selvästi happamampia, joskin päinvastainen ilmiö on tavallisempi. Tämän takia soiden luontaisesta pintakasvillisuudesta voidaan tehdä johtopäätöksiä vain pintakerroksen laatuun nähden.

Soiden alkalinen reaktio saattaa johtua: kalkkipitoisen suon pintaturpeen polttamisesta, kalkkimerkelistä $30-60 \mathrm{~cm}$ syvyydessä, pohjavesien pinnalle tuomista alkalisista suoloista, runsaasti kalkkia sisältävien soiden liiallisesta kalkitsemisesta tai alkalisten kasteluvesien runsaasta käytöstä. Viljeltävien soiden liial- 
linen alkalisuus ei ole eduksi, vaan se voi suorastaan alentaa tuotantoa. Tämä voi johtua liukenevien ja erityisesti alkalisten suolojen liiallisuudesta. Lisäksi emäksinen reaktio vaikeuttaa fosfaattien liukenevaisuutta ja voi estää kasveilta manganin saannin. Eri viljelykasvit suhtautuvat kuitenkin alkaliseen reaktioon jossain määrin eri tavalla.

Turvekerrosten reaktio luokittelun perusteena

Sen lisäksi mitä aikaisemmin on esitetty soiden reaktiosta ja sen vaihteluista, on syytä mainita, että Michiganissa soiden reaktiota käytetään suuressa määrin arvosteltaessa soiden soveliaisuutta viljelytarkoituksiin. Silloin kiinnitetään huomiota sekä pintaturpeen että syvempien kerrosten reaktioon. Harmerin (8) mukaan eroitetaan 10 eri ryhmää. Eri kerrosten $\mathrm{pH}$-luvut vaihtelevat seuraavasti:

$\begin{array}{lccccc}\text { Ryhmä } & 1 & 2 & 3 & 4 & 5 \\ \text { Pintaturve } & 6.4-7.0 & 4.6-6.3 & 4.6-6.3 & 3.0-5.4 & 3.0-4.5 \\ \text { Alempi kerros } & 5.2-7.0 & 4.6-7.0 & 3.0-4.5 & 3.0-4.5 & 5.2-7.0 \\ & & & & & \\ & 6 & 7 & 8 & 9 & 10 \\ \text { Pintaturve } & 4.0-4.5 & 4.6-5.7 & 5.8-8.6 & 7.1-8.6 & 7.1-8.6 \\ \text { Alempi kerros } & 7.1-8.6 & 7.1-8.6 & 7.1-8.6 & 6.4-7.0 & 4.6-6.3 \\ \text { Pohjanmaa } & \text { Merkeliä } & \text { Merkeliä } & \text { Merkeliä } & & \end{array}$

Suurin osa Michiganin soita kuuluu reaktiosuhteiltaan 1. ja 2. ryhmään. Nämä maat eivät tarvitse kalkitsemista, vaan tuottavat asianmukaisesti kuivatettuina ja lannoitettuina hyviä satoja. Ensimmäisen ryhmän maat eivät tarvitse yleensä kuparilannoitustakaan, josta toisen ryhmän maat selvästi hyötyvät.

3. ryhmään kuuluvat suot tuottavat muutamia satoja ilman kalkitustakin mutta myöhemmin se on välttämätöntä suon kasvukunnon ylläpitämiseksi. Niissä tavattava lievemmin hapan pintakerros johtuu ilmeisesti alkuaan hyvin happaman suon polttamisesta tai suon joutumisesta tulvan alle. Alempien kerrosten happamuus saattaa myös aiheutua sulfidien hapettumisen johdosta syntyneistä happamista, veteen liuenneista suoloista. Tähän ryhmään kuuluvia soita on yhdessä 2. ryhmän soiden kanssa hyvin runsaasti Michiganissa. Kuivina kesinä sadot usein jäävät heikoiksi, mutta sateisina vuosina suot kasvavat hyvin, koska kasvien juuret saavat silloin tarpeeksi kosteutta ilman, että niiden tarvitsee tunkeutua syvälle happamiin kerroksiin. Juuri näiden happamien kerrosten oletetaan olevan syynä huonoon kasvuun. Tällaisten kerrosten olemassa olon toteamiseksi suositellaan Michiganissa $\mathrm{pH}$-mittausten tekemistä paitsi suon pintakerroksista myös $50-60 \mathrm{~cm}$ syvyydessa olevista kerroksista. Nämä suot hyötyvät kuparilannoituksesta.

4. ryhmään kuuluu vähän kalkkia sisältäviä, mustikkaa, Cassandraa ja lehtikuusta kasvavia, erittäin happamia soita erityisesti etelä-Michiganista. Nämä suot vaativat runsaan ja tehokkaasti syvälle maahan sekoitetun kalkituksen sekä kuparilannoituksen kaikkia viljelykasveja varten. Niiden raivausta ei nykyään juuri suositella. 


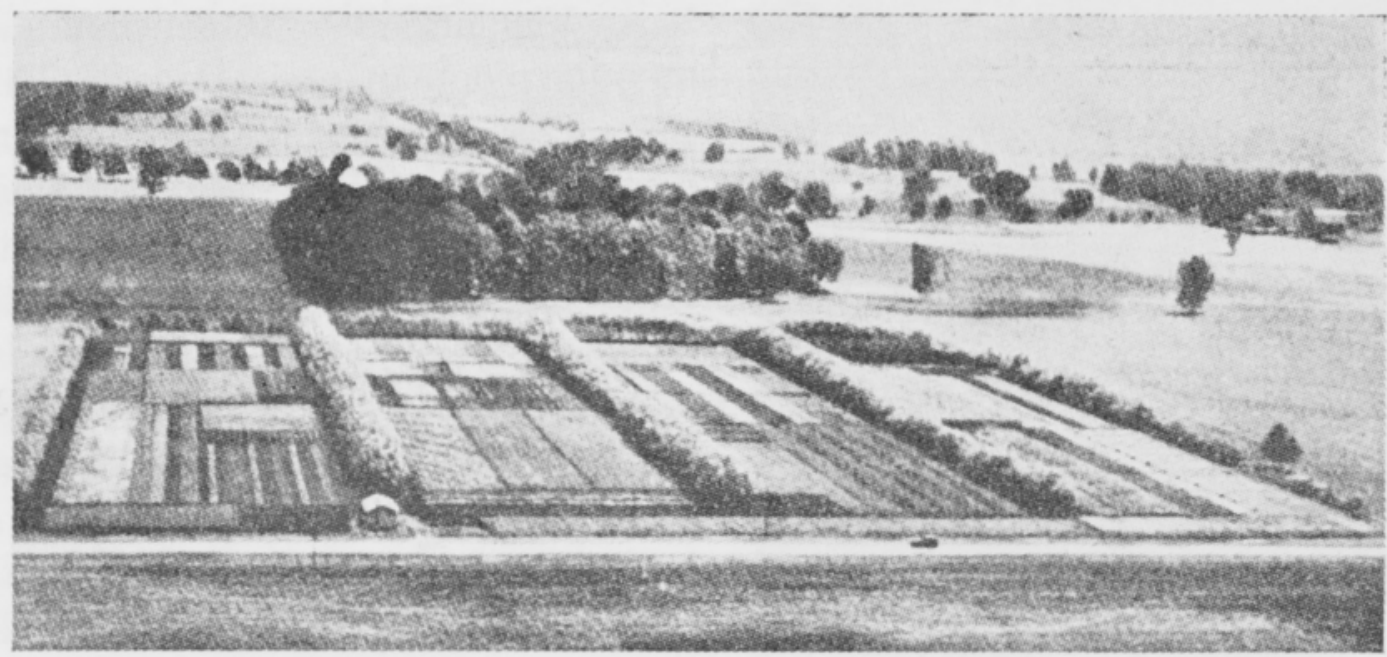

Kuva 7. Suokoeasema lähellä East Lansingia Michiganissa.

Ryhmissä 5. ja 6. on asetelmassa mainittujen kerrosten välissä lievemmin hapanta turvetta. Joskaan merkelipohjaiset suot eivät yleisesti ole kalkituksen tarpeessa, niin eräissä tapauksissa ei niistä ole ilman kalkitusta saatu tyydyttäviä satoja. Kuparilannoitus on myös hyödyksi.

7. ryhmän suot muistuttavat suuresti 2. ryhmän soita. Nekään eivät tarvitse kalkitusta, mutta kuparilannoitus on suotava. Viljelytoimenpiteiden johdosta pintakerrosten kuluessa ja painuessa ne lähenevät ominaisuuksiltaan 8. ryhmän kerrostumia.

8. ja 9. ryhmän alkaliset pintakerrokset eivät sovellu kaikkien viljelykasvien tuotantoon, vaikkapa niille annettaisiin rikkiä ja mangaanisulfaattia happaman reaktion aikaansaamiseksi. Ensiksi mainitun ryhmän soista ovat edullisimpia ne, joiden pintakerrokset ovat happamia, mutta jatkuvan viljelemisen tuodessa alkalisia kerroksia maan pinnalle maan kasvukunto pyrkii heikkenemään. Alkalisille soille on vuosittain annettava rikkiä ja mangaanisulfaattia niiden tuottokyvyn ylläpitämiseksi. Vasta kun liika alkalisuus on saatu poistetuksi, voidaan niiden käytöstä luopua. Boorilannoitus on myös tarpeen. Sitä vastoin ne eivät tarvitse kuparia.

10. ryhmän soita voidaan syväkyntöä käyttämällä viljellä ilman rikkiä. Tällöin nim. alemmat happamat kerrokset sekaantuvat pintakerrokseen ja lisäävät sen happamuutta. Vähäinen rikki- ja mangaanilannoitus on tarpeen sipulia, selleriä ja perunaa viljeltäessä. Viljelyn alkuvuosina ei kuparilannoitus ole yhtä välttämätöntä kuin myöhemmin.

\section{Soiden erosio ja sen vastustaminen}

Maan erosio on Yhdysvalloissa tunnetusti voimakas ja aiheuttaa sangen paljon tuhoa. Sikäläiset turpeet ovat yleensä hyvin maatuneita ja senjohdosta helposti tuulen kuljetettavia. Tätä koetetaan vastustaa mm. pitämällä suot aina kasvillisuuden peitossa. Heti korjuun jälkeen kylvetään suoviljelyksille ohraa, syysruista tai vehnää. Seuraavana keväänä muokkauksen yhteydessä oras sekoitetaan mą- 


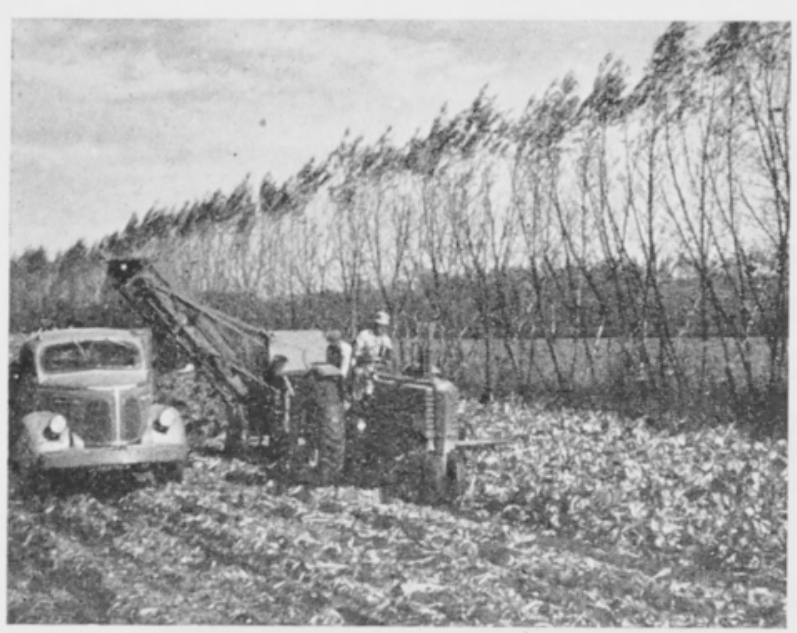

Kuva 8. Pajusuoja-aidoilla estetään soiden erosiota. Etualalla sokerijuurikkaan koneellista nostoa. Michigan. Valok. E. K.

han. Viemärien ja tuulensuoja-aitojen varsilla pidetään useita leveähköjä nurmikenttiä, jotka estävät turvepölyn lentämästä viemäreihin. Vihannesviljelyksiä suojataan heinä- tai maissikaistoilla. Edelleen pohjaveden säännöstelyllä voidaan erosiota vaimentaa. Pohjavesi pidetään yleensäkin sikäläisillä suoviljelyksillä verraten korkealla tasolla ja myrskyjen uhatessa sitä vielä nostetaan. Kosteat pintakerrokset eivät ole yhtä alttiita tuulen tuholle.

Suoja-aidat ovat tyypillisiä Yhdysvaltojen suoviljelyksille. Varsinkin Michiganissa niitä on viime vuosina runsaasti kokeiltu. Vihreätä puumaista pajua käytetään yleisesti näihin aitoihin. Se kasvaa nopeasti ja tällaiset aidat ovat usein 8-10 m korkeita (kuva 8). Aitojen etäisyys toisistaan on n. 250 m. Paitsi pajua on Michiganissa kokeiltu myös havupuita, joista saadaan kyllä tehokas aita, mutta se kasvaa hitaasti. Ainakin koetarkoituksiin on myös käytetty tavallisia lumiaitoja, jopa on kokeiltu purjekankaallakin. Floridan laajoilla suoalueilla on teiden varsille istutettu Itävallan mäntyä tai paikoin bamburuokoa.

\section{Viljelykasveista}

Kun on kysymyksessä niin laaja alue kuin Yhdysvallat, niin on luonnollista että soilla viljeltävät lajit vaihtelevat suuressa määrin. Käytännöllisesti katsoen näyttää siltä, että sikäläisillä soilla voidaan viljellä melkein mitä viljelykasvia tahansa. Erittäin runsaasti niillä viljellään vihanneksia. Esim. Michiganin valtiossa sipuli, selleri ja minttu ovat tärkeimmät soilla viljeltävät lajit. Toisella sijalla mainitaan porkkana, salaatti, pinaatti ja sokerijuurikas. Näiden lisäksi laajat suoalueet ovat maissin ja heinän kasvussa sekä laitumina (4).

Floridan suoviljelyksillä vihannesten viljely on erittäin laajaa, mutta tämän lisäksi siellä kasvatetaan runsaasti monia kuitukasveja. Sokeriruo'on viljely on samoin pääsemässä hyvään vauhtiin. Edelleen laitumena käytetään laajoja alueita. Osoituksena siitä, kuinka monipuolista kasvinviljelyä sikäläisillä suoviljelyksillä voidaan harjoittaa, mainittakoon, että esim. Belle Gladen suokoeaseman kentillä tutkittiin kaikkiaan 29 kasvin viljelyedellytyksiä.

Tässä yhteydessä on syytä mainita vielä, että erittäinkin Massachhusettsin, Michiganin, Wisconsinin ja Oregonin soilla harjoitetaan karpalon (Oxycoccus macrocarpus) viljelyä. Tähän tarkoitukseen soveltuvat parhaiten happamet rahkasuot. Viljelyn onnistuminen edellyttää runsasta veden saantia. Vesi on nim. tärkeä paitsi kasvien elintoimintojen kannalta, tehokas suoja pakkasia vastaan ja sitä käytetään lisäksi moniin viljelyteknillisiin tarkoituksiin. Etenkin suomalaiset ovat paikoin erikoistuneet karpalon viljelyyn. 


\section{Lannoituksesta}

Niin hyvin kivennäis- kuin suomaidenkin lannoituksesta mainittakoon, että etenkin vihannes- ja muilla riviviljelyksillä lannoitteet siroitetaan yleisesti riveihin. Tarkoitukseen käytetään yhdistettyjä kylvö- ja väkilannoitteiden levityskoneita. Täten on mahdollista saattaa lannoitteet siementen välittömään läheisyyteen, joten niiden teho on paljon suurempi kuin hajalleen levitettyinä.

Suoviljelysten typpilannoituksen tarve vaihtelee erittäin paljon ilmastollisten olosuhteiden mukaan. Joskin yleensä typen mobilisaatio on kyllin vilkas korvaamaan typpilannoituksen, niin kylminä ja kosteina keväinä typpilannoitus on pohjoisvaltioissa osoittautunut tarpeelliseksi. Samoin happamissa soissa typen mobilisaatio on niin hidasta, että N-lannoitus on välttämätön. Mitä kaliin ja fosforiin tulee, niin ne molemmat ovat välttämättömiä. Monin paikoin on todettu, että kalilannoitus on välttämättömämpää kuin fosforilannoitus (9). Fosforiperuslannoituksen ohella vaikuttavat nousevat kalimäärät tehokkaasti melkein kaikkien viljelyskasvien satoihin (kuva 9). Meikäläisiä olosuhteita silmällä pitäen on mielenkiintoista todeta, että esim. Michiganissa on soita, joita voidaan viljellä verraten monta vuotta ilman fosfaattilannoitusta. Samoin eräillä soilla on mahdollista saada timoteista ja apilasta 3 jopa useampiakin satoja ilman kalilannoitusta. Voimakasta PK- ja etenkin K-lannoitusta on jo pitkän aikaa käytetty tehokkaana suojana hallaa vastaan (8).

Hivenaineiden saantiin on USA:ssa kiinnitetty erityistä huomiota. Niiden aiheuttamia putostauteja on tavattu melko yleisesti. Vihannesviljelyksillä, joiden reaktio on $\mathrm{pH} 6.5$ tai sen alapuolella käytetään yleisesti kuparilannoitusta. Eräissä tapauksissa kuparilannoitus määräytyy maan reaktion mukaan, kun taas eräiden kasvien kohdalla sitä on käytettävä kaikenlaisissa reaktio-olosuhteissa. Kuparisulfaattia suositellaan $25-50 \mathrm{~kg}$ /ha vuosittain niin kauan, että päästään $250-300$ $\mathrm{kg} / \mathrm{ha}$.

Mangaania suositellaan vihannesviljelyksille, joiden $\mathrm{pH}$ on 6.5 tai sen yli. Se annetaan mangaanisulfaattina. Viime aikoina on suoritettu menestyksellisiä kokeiluja ruiskuttamalla mangaanisulfaattiliuosta suoraan kasvien päälle.

Boorin puutetta tavataan yleisimmin neutraaleilla tai alkalisilla soilla, joilla viljellään juurikasveja, pinaattia, kaalia ja eräitä muitakin kasveja.

Eräissä tapauksissa on myös havaittu sinkin puutetta, etenkin viljelyyn otetuissa soissa. Sen poistamiseksi suositellaan $15 \mathrm{~kg} /$ ha sinkkisulfaattia kahtena tai kolmena ensimmäisenä viljelysvuonna (4). 
Hivenaineiden käyttöä helpoittaa suuresti se, että on saatavissa lannoiteseoksia, joissa on myös hivenaineita.

Meikäläisestä poikkeavaa on tavallisen ruokasuolan käyttö kalilannoituksen yhteydessä. Tämä tulee ennen kaikkea kysymykseen juurikasveille (8). Monissa tapauksissa ruokasuola lisää huomattavasti satoa ja tämän ohella se vaikuttaa oleellisesti sadon laatuun. Sitä suositellaan $500-1000 \mathrm{~kg}$ ha. On olemassa myös soita, joissa suolalla ei ole toivottua vaikutusta.

Eräille alkalisille suoviljelyksille käytetään myös rikkiä lisäämään maan happamuutta mm. mangaanin saannin helpoittamiseksi. Suon reaktiosta riippuen suositellaan rikkiä $300-1000 \mathrm{~kg} / \mathrm{ha}$. Monissa tapauksissa sen käyttö voidaan korvata mangaanisulfaatilla. Rikki levitetään joko keväällä tai syksyllä ja sekoitetaan hyvin maahan. Sen liiallisesta käytöstä voi kuitenkin olla seurauksena huomattavia vahinkoja.

\section{KIRJALLISUUTTA}

(1) Alway, J. F. 1920. Agricultural value and reclamation of Minnesota peat soils. Univ. Minnes. Agr. Exp. Sta Bull. 188

(2) Dachnowsky-Stokes, Alfred P 1933. Peat deposits in USA. Handbuch der Moorkunde 7. Berlin.

(3) Davis, John H. 1946. The peat deposits of Florida, their occurence, development, and uses. Florida Geol. Survey, Bull. 30.

(4) Davis, J. I. 1950. Muck soils, when properly fertilized produce high yields. Plant Food Journ. $4^{3}$.

(5) Clayton, B. S. 1937. Subsidence of Florida peat soil. Transact. of 6th Comm. of Intern. Soc. of Soil Sci, B, p. $340-343$. Zürich.

(6) Feustel, Irvin C. and Byers, Horace G. 1930. The physical and chemical characteristics of certain American peat profiles. U.S. Dept. of Agric. Techn. Bull. 214.

(7) Hammar, Harald Edvin. 1929. The chemical composition of Florida Everglades peat soils with special reference to their inorganic constituents. Soil Sci 28, p. 1-11.

(8) Harmer, Paul M. 1941. The muck soils of Michigan, their management and uses. Michigan State College, Agr. Exp. Sta Special Bull. 314.

(9) Harmer, Paul M. 1952. The nutrition of muck crops. Better Crops. 36.

(10) Jones, Lewis A. 1948. Soils, geology, and water control in the Everglades region. Univ. of Florida, Agr. Exp. Sta. Bull. 442.

(11) Osvald, Hugo 1928 - 29. Mossar och mosskultur i Nordamerika. Sv. Mosskulturför. tidskrift 42, p. $7-31,193-213,330-339$ ja 43 , p. $207-214,261-266$.

(12) Waksman, Selman A. and Stevens, Kenneth R. 1929. Contribution to the chemical composition of peat: III. Chemical studies of two Florida peat profiles. Soil Sci 27, p. 271-281.

(13) Weir, Walter W. 1937. Subsidence of peat land in the Sacramento-San Joaquin delta of California. Transact. of 6 th Comm. of Intern. Soc. of Soil Sci. B, p. 304-314. Zürich.

\section{SUMMARY :}

ON THE PEAT SOILS OF THE UNITED STATES OF AMERICA

ERKKI KIVINEN

University of Helsinki, Department of Agricultural Chemistry, Helsinki.

On the bases of his own observations and literature the author gives a description of the occurence of the peat soils in the USA, their classification, management, and fertilization. 